\title{
Grzegorz Krzywiec
}

Instytut Historii PAN i Zentrum für Antisemitismusforschung TU Berlin orcid.org/0000-0003-1649-866X

gkrzywiec@ihpan.edu.pl

\section{O faszyzmie w wersji polskiej i jego nieoczywistych dziejach raz jeszcze \\ (na marginesie książki Szymona Rudnickiego Falanga. Ruch Narodowo-Radykalny ${ }^{1}$ )}

Szymon Rudnicki, obecnie profesor emerytowany Uniwersytetu Warszawskiego, od kilku dekad należy do najbardziej kompetentnych badaczy polskiej prawicy w jej rozmaitych wersjach, od różnych odcieni Narodowej Demokracji przez polskich konserwatystów po oblicza politycznego katolicyzmu. Rudnicki pozostaje także jednym z największych autorytetów w badaniach dziejów polskich Żydów od końca XIX do pierwszej połowy XX w.

Od lat komentuje istotne studia $\mathrm{z}$ dziejów antysemityzmu i zabiera głos w ważnych dyskusjach dotyczących relacji polsko-żydowskich. Jest też historykiem-instytucją; „chodzącą encyklopedią” przy wielu typach źródeł i dokumentów: od sprawozdań sejmowych, dokumentów urzędowych, przez często rozproszone po świecie świadectwa osobiste, aż do dokumentacji okolicznościowej. Od doktoratu obronionego w 1968 r. poświęconego genezie Obozu Radykalno-Narodowego (ONR) - praca została wydana drukiem dopiero w 1985 r. - pozostaje jednym z najwybitniejszych znawców polskiego nacjonalizmu w zasadzie we wszelkich jego odmianach.

Przywołana $\mathrm{w}$ podtytule monumentalna praca - efekt wieloletnich studiów i poszukiwań archiwalnych - składa się z dwóch obszernych części. Część pierwsza obejmuje rozdziały poświęcone rozwojowi, ewolucji i schyłkowi formacji politycznej wyrosłej z podziału ONR, a w zasadzie jego bardziej ekstremistycznego, mającego najdalej idące społeczno-polityczne postulaty i aspiracje odłamu, ONR-Falangi, zwanego okresowo od inicjałów czołowego przywódcy Bolesława Piaseckiego „bepistami”, potem przekształconego w Ruch Radykalno-Narodowy. Te partie książki to głównie dalsze losy oraz ewolucja wspomnianej grupy i zbliżonego do niej środowiska, rozpisane na poszczególne etapy

${ }^{1}$ Szymon Rudnicki, Falanga. Ruch Narodowo-Radykalny, Warszawa: Wydawnictwo ASPR-JR, 2018,843 s. 


\section{4}

działalności i aspekty funkcjonowania publicznego (m.in. przemoc polityczna, miejsce i rola wyższych uczelni czy bardzo szczegółowo związki i relacje z prawicowymi ugrupowaniami i środowiskami politycznymi, od pozostającego ciągle w centrum życia politycznego Stronnictwa Narodowego przez różne odpryski organizacji rozłamowych po obóz rządzący, czyli sanację). Autor w tej części monografii szczegółowo rozdzielił materiał na poszczególne grupy polityczne; m.in. rozłożył na czynniki pierwsze zasięg i miejsce wpływów Falangi na prawicowo-nacjonalistycznej scenie politycznej. Wedle podanych szacunków i obliczeń był on znacznie większy i, jak wiele wskazuje, dalej idący, niż się zwykle w literaturze przedmiotu przyjmowało. Te fragmenty pracy jasno i dowodnie pokazują, jak, gdzie i kiedy zamysł zdobywania władzy, postulowany przez niekwestionowanego lidera tej grupy Bolesława Piaseckiego, przybierał realne kształty.

Część druga obejmuje kwestie, które autor zbiorczo traktuje jako „myśl polityczną", a więc zarówno doktrynę polityczną ugrupowania, podstawowe pojęcia i toposy dyskursu (m.in. religię, naród, nacjonalizm, imperializm i totalitaryzm etc.), jak i kategorie centralne dla retoryki politycznej (m.in. organizację polityczną narodu, przełom narodowy, wspólnotę narodową, cywilizację polską) czy też rozpisane szczegółowo elementy programu politycznego (m.in. ustrój społeczno-polityczny, miejsce gospodarki i kultury czy wizje historii), a także relacje z innymi grupami etnicznymi. W tej części książki szczegółowo zostały rozpisane miejsce i rola antysemityzmu. Blisko jedną trzecią zawartości studium stanowią szczegółowe analizy najważniejszych enuncjacji prasowych, czy szerzej publicystycznych, nie tylko formacji Piaseckiego, ale i obozu nacjonalistycznego, podzielone i zanalizowane w drobniejszych passusach.

Nie ulega najmniejszej wątpliwości, że jest to najważniejsza, najbardziej precyzyjna w rekonstrukcji i detaliczna w warstwie źródłowo-dokumentacyjnej krytyczna analiza, obejmująca opis i drobiazgowy rozbiór na części pierwsze projektu ideologicznego tego odłamu polskiej prawicy nacjonalistycznej. Dla większości badaczy - jej faszystowskiego czy jak wielu woli faszyzującego odłamu. Obóz Narodowo-Radykalny czy sama Falanga (Ruch Narodowo-Radykalny) to bowiem esencja polskiego faszyzmu (m.in. Antoni Dudek i Grzegorz Pytel, Andrzej Jaszczuk, Krzysztof Kawalec, Mikołaj Kunicki etc.). Obraz maszerujących Nowym Światem bojówkarzy ONR jest niemal ikoniczny dla polskiego rozumienia tego fenomenu ${ }^{2}$. Czy polski faszyzm to jednak tylko Falanga?

Studium Szymona Rudnickiego skupia się na elitach i przywódcach polskiego narodowego radykalizmu, choć często także młodego polskiego nacjonalizmu - zwykle (choć nie tylko) młodych mężczyznach świetnie wykształconych, często wyrafinowanych kulturalnie, zdolnych do formułowania

${ }^{2}$ Czesław Miłosz, Faszyzm (1945) [w:] idem, W cieniu totalitaryzmów. Publicystyka rozproszona z lat 1945-1951 oraz teksty z okresu II wojny światowej, red. Aleksander Fiut, Kraków: Wydawnictwo Literackie, 2018, s. 21. 
samodzielnych, niebanalnych i krytycznych sądów. Wielu z nich to synowie działaczy politycznych i osobistości najwyższego szczebla ogólnopolskiego; profesorów, wybitnych prawników, lekarzy, wysokich urzędników państwowych, w tym wojskowych, z których wielu mogło sobie pozwolić na styl życia nierezonujący z doświadczeniem egzystencjalnym większości mieszkańców Drugiej Rzeczypospolitej. Łączyły ich więc przynależność do establishmentu społeczno-kulturowego, przekonanie, że są prawowitymi następcami rodzimej elity, a zarazem poczucie, że pozostają od niej odsunięci. Trudno uznać ich za zagubione pokolenie, nawet jeśli część z nich nie chciała i nie potrafiła odnaleźć się w realiach państwa polskiego po 1926 r. To wszystko nie oznacza jednak, że w pewnym momencie historycznym ci młodzi nie zdefiniowali się w swej masie jako reprezentanci Polski peryferyjnej, czy to wiejskiej, czy wręcz - jak w wypadku Falangi - drobnomieszczańsko-lumpenproletariackiej. Dla przypomnienia: Falanga (potem Ruch Narodowo-Radykalny) to przecież idący najdalej w swoich projekcjach ustroju "narodowego” odłam polskiego nacjonalizmu powstały z jednej z grup rozłamowych, które wyłoniły się z frondujących środowisk nacjonalistycznych.

Czy jednak czołowi działacze, a co z tym idzie zwykle w parze, ideologowie pierwszego, formacyjnego ONR (1934) proponowali na tle swojego pokolenia tj. innych ugrupowań wywodzących się z Ruchu Młodych Obozu Wielkiej Polski, formacji powstałej w 1927 r. - coś nowego i oryginalnego, czego nie napisaliby i ogłosili już wcześniej publicyści tego kręgu, a praktykowali ich rówieśnicy? Żadna z publikacji, które wyszły ze środowiska ONR - a w znakomitej większości były to broszury, rzadziej większe formy jak traktaty polityczne (autorstwa Jan Mosdorfa czy ideologów, którzy ostatecznie pozostali w obrębie SN, Jędrzeja Giertycha i Adama Doboszyńskiego) - nie trafiła do annałów rodzimej myśli politycznej. Główni ideologowie, jak wspomniany Mosdorf (jego praca pt. Wczoraj i jutro z 1938 r. jest ciągle wznawiana na polskim rynku księgarskim jako „biblia polskiego narodowego radykalizmu”) czy Tadeusz Gluziński, potem już sam Bolesław Piasecki, a także Włodzimierz Sznarbachowski, Marian Reutt oraz twórcy z kręgu „Ruchu Kulturalnego”, nie pozostawili po sobie tekstów, które zaznaczyły się szczególnie w dziejach rodzimej myśli i idei. Autor prezentowanego tu studium skrzętnie odnotowuje, że tylko jeden uniwersytecki profesor (t). Zygmunt Cybichowski ${ }^{3} \mathrm{z}$ Uniwersytetu Warszawskiego) wsparł swoim autorytetem i pozycją ONR w polityce. Podążając za rekonstruowanymi przez Rudnickiego nurtami, można by przyjąć, że Falanga (RNR) to organizacja niszowa, by nie rzec studencka, z małym wpływem na rzeczywistość społeczno-polityczną II RP.

\footnotetext{
${ }^{3}$ Cybichowski doczekał się odrębnej monografii, w której został przedstawiony jako niemal czołowy teoretyk prawa Drugiej Rzeczypospolitej (Adam Danek, Demokracja nacjonalistyczna. O myśli politycznej Zygmunta Cybichowskiego, Kraków: Ośrodek Myśli Politycznej, 2018). Jak w większości publikacji dotyczących radykalnej prawicy, autor tej drobiazgowej rozprawy sam jest czynnym działaczem ruchów prawicowych.
} 
Z nie do końca wiadomych przyczyn - pozostawiając na boku urojenia tzw. prawicowej historiografii - trzeba by też uznać, że wyrosła na swego rodzaju czarnego Piotrusia polskiej historii XX w., jak nota bene wytrwale przekonują jej rodzimi apologeci. Tak jednak nie było. Wiele wskazuje na to, że Falanga stanowiła być może najbardziej spektakularny symptom szerszej i głębszej transformacji, przekształcającej całe ówczesne życie publiczne.

Centralnym punktem odniesienia dla polskiego faszyzmu - pokazują to nie tylko wszystkie wydane, $\mathrm{w}$ tym te redagowane przez autorów sympatyzujących ze skrajną prawicą, antologie tekstów, a obszerne partie monografii Szymona Rudnickiego także to sugestywnie dokumentują - byli Żydzi i ich rzekoma wrogość wobec wspólnoty narodowej. Ta wrogość - jak dowodnie wykazał gdzie indziej autor recenzowanej tu pracy - miała charakter, cechy i naturę totalną i zasadniczo odróżniała młody nacjonalizm lat trzydziestych XX w. od starszych pokoleń i innych grup politycznych. Nie tyle zatem antysemityzm polityczny właściwy dla całej ówczesnej centroprawicowej sceny, ile radykalny antysemityzm eliminacyjny stanowił clou ich zapatrywań. Nie ma chyba większego sensu skupiać się na tym, czy to czynniki ekonomiczne, czy raczej polityczne, pseudohistoryczne albo tzw. biologiczno-rasowe odgrywały tam główną rolę. Każdy przypadek wypadałoby analizować odrębnie, a taka aptekarska wyliczanka na pewnym etapie i tak stałaby się jałowa. Czy kogoś powinno dziwić, że najwięcej „rasowych” uzasadnień wrogości Żydów można znaleźć na łamach opiniotwórczej dla głównego nurtu Narodowej Demokracji „Myśl Narodowej” oraz w wydaniu codziennym „Gazety Warszawskiej”, a najliczniejsza frakcja rasowo-antropologiczna (m.in. prof. Karol Stojanowski i Ludwik Jaxa-Bykowski) stanowiła trzon ultrakatolickiej tzw. grupy Kowalskiego-Giertycha, ideowego zaplecza Stronnictwa Narodowego w okresie między jesienią 1937 a czerwcem 1939 r.? Podobnie zdeklarowanym rasistą byli czołowy publicysta nacjonalistyczny i raczej drugorzędny dramaturg Adolf Nowaczyński, nie tylko we wpływowych środowiskach historycznych, lecz także wśród współczesnych badaczy literatury cieszący się uznaniem jako postać co najmniej nietuzinkowa ${ }^{4}$, jak również Zygmunt Wasilewski, Stanisław Kozicki czy Stanisław Pieńkowski, redaktorzy naczelni najważniejszych periodyków nacjonalistycznych już od pierwszej dekady $\mathrm{XX}$ w., a zarazem otwarci wyznawcy teorii rasowych.

Już dla polskiego „narodowca” z przełomu wieków (XIX i XX) „Żyd” zasadniczo nie mógł zostać Polakiem, co więcej, był też z natury wrogiem polskości i rodzimej wspólnoty narodowej. Jeszcze przed wybuchem Wielkiej Wojny polski nacjonalizm domagał się $w$ tym zakresie jednoznacznych, niemal totemicznych identyfikacji: Polak albo Żyd. Generacje międzywojenne zaś odczuwały jakąkolwiek współegzystencję Polaków z Żydami jako swego rodzaju

${ }^{4}$ Z bojów Adolfa Nowaczyńskiego. Wybór źródeł, t. 3: W cieniu swastyki (1932-1934), red. Arkadiusz Meller, Sebastian Kosiorowski, Warszawa: Wydawnictwo von Borowiecki, 2018, s. 260 . 
koszmar nie do zniesienia, z którego całe pokolenie chciało się jak najszybciej wyzwolić.

Dla wielu ideologów i publicystów tej nowej formacji pod radykalnie antysemicką warstwą kryła się często precyzyjna krytyka ówczesnego świata; kapitalizmu w wydaniu peryferyjnym, najczęściej jednak patologicznego kształtu, jaki miało rzekomo przyjąć odrodzone państwo polskie. Większość z przywódców młodoendeckich zbliżała się do tych radykalnych identyfikacji, jednocześnie zachowując wobec nich pewien dystans. Żadna z wizji wyartykułowanych w kręgu Falangi - nawet w tych artystycznych projektach z otoczenia Polskiej Akcji Kulturalnej (POAK) czy śląskiej „Kuźnicy” - nie zawierała projektu wyzwolonej „wspólnoty narodowej”, której członkowie po pozbyciu się „Obcych-Innych” byliby wobec siebie równowartościowi. Wręcz przeciwnie, odrodzenie, regeneracja narodu - a więc cel tego, co obecnie definiujemy jako faszyzm - miały nastąpić przez ścisły podział ról społecznych (w tym płciowych); powrót do „prawa naturalnego", nową hierarchizację z przypisaniem jednostce jednoznacznych tożsamości, których nie da się negocjować, a przekroczyć je bardzo trudno, jeśli w ogóle to możliwe. Najważniejsza dla całej formacji młodoendeckiej koncepcja „Organizacji Politycznej Narodu” to w istocie przepisane pomysły Romana Dmowskiego jeszcze z pierwszej dekady XX w. Kwestią dyskusyjną pozostaje za to, w jakim stopniu i czy w ogóle kluczem do polskiego faszyzmu - jak uważa Rudnicki, a wraz nim większość rodzimych badaczy - był projekt totalitarny, właśnie w środowisku Falangi otwarcie i najpełniej wyrażany. Po pierwsze, sam zamysł społeczeństwa totalitarnego - koncept rozwijany, począwszy od lat pięćdziesiątych XX w., głównie w politologii amerykańskiej - wydaje się coraz mniej adekwatny do opisu praktyk klasycznych reżimów faszystowskich (w Niemczech, we Włoszech; jako totalitarni mogą się jawić np. niemieccy nacjonalbolszewicy; wąski i marginalny nurt wobec „nietotalitarnej” programowo NSDAP) oraz pomniejszych ruchów. Po drugie, sama koncepcja totalnej reorganizacji społeczeństwa $\mathrm{w}$ ruchach radykalnej prawicy już u zarania podlegała różnym fluktuacjom i zastrzeżeniom, tak że trudno byłoby obronić tezę o ich totalitarnym charakterze. Ważniejsze wydają się praktyki społeczne, a znakomita większość ruchów faszystowskich i faszyzujących nigdy tak naprawdę nie doszła do pełnej władzy, nie miały zatem możliwości tworzyć reżimu faszystowskiego. Tak też było w przypadku polskim.

Praca Szymona Rudnickiego pokazuje oprócz źródeł atrakcyjności i sporego sukcesu w niektórych kręgach społecznych także powolne wyczerpywanie się kapitału politycznego Piaseckiego i jego towarzyszy, którzy jeszcze w latach 1935-1937 uosabiali nadzieje, urok i aspiracje nie tylko polskiego nacjonalizmu, lecz niemal całej polskiej prawicowej sceny politycznej (często powracające we wspomnieniach niezależnych od siebie świadków opisy charyzmy Piaseckiego - impulsywnej natury narzucającej otoczeniu swoją wolę - jego pasji i idealizmu młodości oraz nietuzinkowych talentów politycznych - nie wydają się przesadne). 
Niemniej procesy, o których pisze i wokół których ogniskuje swój wywód Szymon Rudnicki, miały szerszy i, jak się zdaje, głębszy - dalekosiężny i niedający się wprost oszacować - zasięg. Pośrednio wskazuje na to wielokrotnie sam autor. Procesy te nie dotyczyły tylko wąskiej grupy środowisk akademickich, z których powstał i rozwinął się ONR, a potem konstytuowała się Falanga, ale obejmowały liczne inne grupy społeczne. Dlatego też w narracji często przywoływane są wydarzenia, epizody i fakty z głównych nurtów polskiego nacjonalizmu drugiej połowy lat trzydziestych XX w. Innym słowy, „polski faszyzm” to zjawisko i fenomen rozleglejszy, bardziej ekstensywny, a przy tym zagadnienie trudniej uchwytne, niż wskazują dotychczasowe ustalenia.

Rok 1935 - rok śmierci Józefa Piłsudskiego i początku instytucjonalno-ideowych przekształceń obozu rządowego - upublicznił rozmaite procesy wewnątrz elity władzy, a także te zachodzące w największym środowisku opozycyjnym. Gromadzenie się autorytarnych, w tym faszyzujących sił w obrębie obozu Piłsudskiego zaczęło się znacznie wcześniej, zaraz po $1926 \mathrm{r}$. Na początku lat trzydziestych nabrało jednak nowego tempa, choć dyktator trzymał swoich „zamordystów” ciągle na krótkiej smyczy. Śmierć Piłsudskiego jako moment historyczny, patrząc nań retrospektywnie, nie stanowiła zatem żadnego ideologicznego zwrotu w ramach szeroko rozumianego ruchu nacjonalistycznego. Inaczej wyglądało to na planie społecznym i politycznym. Usuwanie się Piłsudskiego z centrum władzy wraz z ujawnionym kryzysem legitymizacji elit sanacyjnych zbiegło się z domknięciem ewolucji polskiego nacjonalizmu, w którym poza nielicznymi wyjątkami władza dostała się w ręce „młodych”. Ten „moment polityczny” został już wielokrotnie opisany i udokumentowany; gorzej, jak się zdaje, przyswajane są konsekwencje kulturowo-społeczne tego przesilenia, które w ostateczności dotknęło całą scenę polityczną. Jak wspomniałem, w latach po 1935 r. w kulturze politycznej doszło do niemal kompletnej marginalizacji tej części polskiego nacjonalizmu, która opierała się presji subkultury paramilitarnej i rodzimych wersji faszyzmu, gwałtownego słabnięcia demokratycznej lewicy, często kosztem dogmatycznych i bardziej bezwzględnych komunistów, a jednocześnie do bezprecedensowego na rodzimą skalę przypływu nowych idei, formuł i mentalności autorytarnej.

W wypadku największej, prawie 200-tysięcznej, a z zapleczem społecznym liczącej przynajmniej drugie tyle partii politycznej, tj. Stronnictwa Narodowego, oznaczało to niemal wewnętrzną rewolucję. Symboliczne jest z jednej z strony powołanie Komitetu Głównego SN - organu składającego się z rywalizujących ze sobą frakcji „młodych” - swego rodzaju kolektywnej dyktatury o praktycznie nieograniczonych kompetencjach w zarządzaniu stronnictwem, z drugiej zaś na samym dole - drużyny, komórki niższej od koła partyjnego, mającej w istocie paramilitarne i bojówkarskie zadania i cele. Te dwa ciała wraz z tworzonymi odgórnie wydziałami gospodarczymi (de facto stanowiącymi bieżący antyżydowski sztab bojkotowy) i Strażą Porządkową (rodzaj sformalizowanej milicji partyjnej od 1936 r.) określiły miejsce, rolę i dynamikę polskiego nacjonalizmu na 
scenie politycznej. Ważną rolę zaczęli też odgrywać tzw. kierownicy polityczni, będący zarazem odgórnie mianowanymi liderami i uformowanymi już żołnierzami politycznymi nowego typu ${ }^{5}$.

Choć wielu badaczy zdaje się ten przełom ciągle przeoczać6 , jego konsekwencje trudno przecenić. O ile już w latach 1931-1932 Obóz Wielkiej Polski, największa masowa organizacja nacjonalistycznej prawicy, pod faktycznym wpływem swojej organizacji młodzieżowej, tj. Ruchu Młodych, i z błogosławieństwem jego założyciela Romana Dmowskiego, stawał się organizacją bojówkarską, o tyle delegalizacja i późniejsze włączenie byłych członków OWP do SN (1933), a potem utworzenie Sekcji Młodych SN przyniosło militaryzację całego ruchu nacjonalistycznego. Wszystkie późniejsze secesje, rozłamy i frondy - identyfikowane z powstaniem ONR i Związku Młodych Narodowców, a także pomniejszych grup i środowisk - zwykle określane jako „przełom faszystowski” w polskim nacjonalizmie (stąd m.in. „przełomowy rok 1934” w książce Rudnickiego), wydają się mieć $\mathrm{w}$ tej perspektywie znaczenie drugorzędne. Wszystkie te grupy bowiem odwoływały się do wspólnego ideowego i instytucjonalnego dziedzictwa OWP, wszystkie czerpały z doświadczeń i praktyk tej organizacji. Żadne w praktyce nie zdobyło się na jego przezwyciężenie. Co więcej, procesy te, choć nie liniowo i nie zawsze wprost i bezpośrednio, dotyczyły całej formacji nacjonalistycznej ${ }^{7}$.

Z pewnością ważnym punktem odniesienia dla „polskiego faszyzmu” jest stosunek wszystkich odłamów „młodych” do Romana Dmowskiego. Ten nieformalny przywódca całego ruchu nacjonalistycznego już od pierwszej połowy lat dwudziestych szukał społecznego nośnika swoich własnych projektów i zarazem fantazji politycznych. Pod koniec dekady, w obliczu nadciągającego kryzysu społeczno-gospodarczego, znalazł narzędzia i przekaz polityczny pozwalające wykorzystać nastroje niepokoju społecznego, najpierw głównie wśród prawicowej młodzieży, potem także w jakieś mierze wśród tzw. klas ludowych. To istotne novum na tle wcześniejszych dziejów rodzimego nacjonalizmu, nie dość rozpoznane i przyswojone. Polski nacjonalizm w odróżnieniu od wcześniejszych epok nie tyle bowiem chciał młode pokolenia „dyscyplinować”, ile po raz pierwszy, i to na taką skalę, wykorzystać. Użyć w boju. W dużej mierze dzieje „polskiego faszyzmu" można jednak rozumieć zarazem jako formę emancypowania się młodego pokolenia od dziedzictwa i osoby Dmowskiego. Czy i w jakim stopniu udaną, to ciągle niedopowiedziana i po części niejednoznaczna historia. Stosu-

\footnotetext{
${ }^{5}$ Por. Robert Rudnicki, Wiesław Ignacy Renke (1912-1944). Życie i działalność kierownika politycznego Obozu Narodowego, Warszawa: Prohibita, 2018.

${ }^{6}$ Ostatnio por. Aneta Dawidowicz, Myśl polityczna Stronnictwa Narodowego 1928-1939, Lublin: Wydawnictwo UMCS, 2017.

${ }^{7}$ Ich genezę, m.in. wprowadzenie do dyskursu nacjonalistycznego elementów ekstremistycznych od samego początku, pokazuje badacz, który paradoksalnie stara się odciąć rodzimy nacjonalizm od europejskiego faszyzmu, Jarosław Tomasiewicz (idem, Naprawa czy zniszczenie demokracji? Tendencje autorytarne i profaszystowskie w polskiej myśli politycznej 1921-1935, Katowice: Wydawnictwo Uniwersytetu Śląskiego, 2012, w szczególności s. 126-213).
} 
nek Dmowskiego do faszyzmu także wydaje się złożony; do ostatnich swoich dni myślał o swoistej lokalnej wersji tego fenomenu, jakby nie do końca mogąc się dopasować do obcych wzorów i szukając własnych odpowiedzi na dylematy analogiczne do tych, przed jakimi stanęła po pierwszej wojnie światowej europejska prawica. To, co wiemy na pewno, to że nie znalazł następcy, co w dużej mierze zaważyło na instytucjonalnym i organizacyjnym rozproszeniu polskiego nacjonalizmu w latach trzydziestych.

Bliższy wgląd w oblicze życia publicznego lat trzydziestych XX w. pokazuje jednak, że postępująca faszyzacja nacjonalistycznej polityki - już na początku dekady wybitny socjolog Aleksander Hertz przenikliwie zdiagnozował ten proces jako „militaryzację stronnictw politycznych”, nie zawężając tego bynajmniej do rodzimego nacjonalizmu - organicznie wiązała się z praktykami eliminacyjnymi wobec Żydów, a także, o czym się zwykle zapomina, wobec innych mniejszości. Całościowy nacjonalistyczny projekt usuwania z przestrzeni publicznej wrogów wspólnoty narodowej okazywał się przemyślaną i dalekosiężną strategią mającą oddziaływać na wyobraźnię i postawy zasadniczo wszystkich aktorów życia społecznego. Kryzysowi gospodarczo-społecznemu, pogłębiającemu się przeświadczeniu o końcu starego kapitalistyczno-burżuazyjnego świata - znowu fenomen zasadniczo identyfikowany raczej przez polskich literaturoznawców niż historyków - a przy tym eksplozji demograficznej na wsi, potęgującej problemy wynikające z wadliwej struktury społecznej, towarzyszył zamysł wywołania „rewolucji narodowej”, tj. nakręcenia fali agresji antyżydowskiej, która pierwotnie skierowana przeciwko Żydom, miała uderzyć w rządy sanacji („żydosanacji”), potem lewicę („fołks-front”), a w dalszej kolejności dotyczyć wszystkich pozostałych uczestników życia politycznego.

Jak pokazują cząstkowe studia z kilku lokalnych ośrodków (m.in. Piotra Cichorackiego, Kamila Kijka, Krzysztofa Muchy, Henryka Lisiaka, Krzysztofa Osińskiego czy Przemysława Olstowskiego), trwający od początku lat trzydziestych XX w. ferment wśród młodzieży akademickiej, połączony z pogłębiającą się pauperyzacją warstw ludowych, nałożył się na postępującą delegitymizację ustroju „pomajowego” również na polskiej prowincji. Narastającej pustce ideowej, której towarzyszyły często brutalne przepychanki w obrębie elit sanacyjnych, sprzyjały poszukiwania nowej formuły politycznej po stronie rządowej ${ }^{8}$. Najbardziej spektakularny i zarazem ciągle społecznie zapoznany fragment tego procesu to próba przeszczepienia zideologizowanej wrogości wobec Żydów na prowincję. Szymon Rudnicki wspomina o tym zjawisku wielokrotnie, być może jako jeden z pierwszych zdiagnozował i opisał ten fenomen, ale jego skala i dalekosiężne konsekwencje, często przeoczone, ujawniające się bowiem

\footnotetext{
${ }^{8}$ Wśród ostatnio opublikowanych studiów należy wymienić książkę Tomasza Sikorskiego Żelazny krok potężnych zdyscyplinowanych szeregów... Oblicze ideowo-polityczne środowiska „Zaczynu” (1936-1939). Studium z dziejów myśli politycznej piłsudczyków (Warszawa: Wydawnictwo von Borowiecky, 2014).
} 
po latach, i to w sposób nieoczywisty, wymagają dalszych pogłębionych mikrostudiów.

Zasadniczo w tej ogólnopolskiej kampanii terroru zarówno ONR-ABC, jak i kluczowa dla tych rozważań Falanga (RNR), tj. główni bohaterowie studium Rudnickiego, nie wspominając o innych organizacjach rozłamowych, miały drugorzędne znaczenie. Po rozpadzie ogólnopolskiej organizacji „narodowego radykalizmu" ośrodki obu tych partii powstawały jeszcze w kilku ośrodkach miejskich, rzadziej na prowincji ${ }^{9}$. Poza stołeczną Warszawą, a także kilkoma ośrodkami akademickimi w gruncie rzeczy nigdzie nie zapuściły trwałych korzeni. W żadnym z nich nie osiągnęły takiej dynamiki, ażeby załamać bądź gruntownie zachwiać lokalną sceną polityczną. Na pierwszy plan wysunęło się za to należące do głównego nurtu Stronnictwo Narodowe. Proces radykalizowania się czołowej partii opozycyjnej, a zarazem największej masowej organizacji politycznej tego czasu nie jest dla historyków niczym nowym; jego wszechstronne konsekwencje, $w$ tym przede wszystkim dla polskiej prowincji, pozostają jednak w dużej mierze nierozpoznane. Trzeba bowiem przyjąć, że Stronnictwo Narodowe nie tylko przekształca się w ugrupowanie faszystowskie, $\mathrm{w}$ dużej mierze o charakterze paramilitarnym, lecz także w dość znaczący sposób zmienia się dramatycznie jego struktura społeczna. Znowu, jako pokazują cząstkowe studia z kilku regionów (przede wszystkim Zygmunta Kaczmarka, a ponadto Henryka Lisiaka, Krzysztofa Muchy, Krzysztofa Osińskiego), SN staje się tzw. partią ludową $^{10}$. Odzwierciedliło się to w przemocy politycznej.

Klasycznym, niemal podręcznikowym przykładem przeniesienia „rewolucji narodowej" na prowincję wydają się rozruchy antyżydowskie w podradomskiej miejscowości Przytyk wiosną $1936 \mathrm{r}^{11}$ Sprowokowane przez bojówkarzy endeckich wypadki doprowadziły do wybuchu zamieszek, w których wyniku polscy chłopi z okolicznych wiosek, uczestnicy dorocznego targu, zaatakowali żydowskich mieszkańców Przytyku. W miejscowości, gdzie istniała „żydowska samoobrona" - inny symptom tamtego czasu - doprowadziło to do reakcji zwrotnej i skończyło się na ofiarach śmiertelnych po obydwu stronach. Podobnych prób rozniecenia żagwi „rewolucji narodowej” na polskiej prowincji było setki, jeśli nie tysiące. Nie wszędzie trafiły, jak w Przytyku czy w Myślenicach, na tak sprzyjające warunki. Niemal wszędzie siały spustoszenie w lokalnej tkance społecznej.

\footnotetext{
${ }^{9}$ Do wyjątków należy Podlasie; por. Mariusz Bechta, Narodowo radykalni. Obrona tradycji i ofensywa narodowa na Podlasiu w latach 1918-1939, Biała Podlaska: Rekonkwista, 2014. Praca ta, pisana z pozycji apologetycznych wobec polskiego nacjonalizmu, zawiera sporo interesującego materiału, pokazującego, jak społeczności wiejskie i małomiasteczkowe ulegały w latach trzydziestych XX w. postępującej radykalizacji nacjonalistycznej.

${ }^{10}$ Por. Stanowisko Stronnictwa Narodowego, „Myśl Narodowa”, 2 V 1937, nr 18, s. 276.

${ }^{11}$ Ostatnio temu zjawisku w województwie kieleckim i okolicach kilka tekstów w nowatorskim ujęciu poświęcił Kamil Kijek; zob. m.in. idem, Zanim stał się Przytyk. Ruch narodowy a geneza zajść antyżydowskich w wojewódzkie kieleckim w latach 1931-1935, „Zagłada Żydów. Studia i Materiały" 2018, nr 14.
} 
W dłuższej perspektywie widać jednak, że prowadzona od miesięcy akcja bojkotowa stanowiła tylko część zamysłu mającego na celu wzajemne antagonizowanie Polaków i Żydów. Jej celem było nie tyle „emancypowanie się” ludności polskiej od Żydów, jak przedstawiała to zwykle nacjonalistyczna kampania propagandowa z epoki, a często powtarzają współcześni apologeci, nie dostrzegając pośledniego, uzależnionego od roli państwa i jego administracji miejsca Żydów w strukturze społecznej, ile wywoływanie atmosfery - Michał Borwicz nazwałby to „organizowaniem nienawiści” - w której współżycie Polaków i Żydów stawało się niemożliwe.

Przykład Przytyku, a także Grodna, Częstochowy, Mińska Mazowieckiego, Odrzywołu czy kilkudziesięciu, może nawet kilkuset miejscowości zwykle nieobecnych w pamięci społecznej unaocznia, że zwykle między akcją bojkotową, ogólnopolskimi falami retorycznej nienawiści na łamach prasy nacjonalistycznej a aktami przemocy wobec Żydów, w tym prowokowaniem zamieszek o charakterze masowym, istniała organiczna ciągłość. Niemal wszyscy oskarżeni w procesie przytyckim po „stronie polskiej” byli członkami SN. Podobnie w innych miejscowościach, gdzie nastąpiły największe pogromy i ekscesy antysemickie. Ten schemat powtarzał się z jednej strony w wielkoprzemysłowej Łodzi i na Śląsku, a z drugiej w rolniczym północnym Mazowszu, w Łomżyńskiem, na Podlasiu i Lubelszczyźnie. Podobnie odbywało się to w Wielkopolsce i na Pomorzu, gdzie kilka procent Żydów niknęło w morzu chrześcijańskiej ludności. W Gdyni, gdzie ogólnonarodowa akcja bojkotowa Żydów została zapoczątkowana w 1932 r., a więc nieco później niż całym kraju, i gdzie organizacje rozłamowe (jak ABC czy Falanga) zyskały znikome wpływy, bojkot od razu przeradzał się w wywoływanie aktów agresji wobec Żydów. Ten drobny z pozoru epizod wydaje się charakterystyczny dla zrozumienia nie tylko ogólniejszej atmosfery tamtego czasu, lecz także dynamiki przemocy.

„Pikietnicy”, w propagandzie hołubieni jako „żołnierze polityczni” - Jędrzej Giertych przyrównywał ich do walecznych obrońców „chrześcijańskiej” Hiszpanii w wojnie domowej - to bowiem działacze, którzy bezpośrednio uczestniczyli $\mathrm{w}$ fali terroru, choć partia często wykorzystała również opłaconych uprzednio lokalnych kryminalistów bądź bezrobotnych. „Gdynia” w nacjonalistycznym imaginarium uchodziła za miasto szczególnie „zażydzone” w wyniku polityki sanacyjnej. Nie bez powodu pierwszy ogólnopolski zjazd Ruchu Młodych OWP z 1930 r. zorganizowano właśnie tam. Skończył się ogólną bijatyką ze służbami policyjnymi i z przeciwnikami politycznymi. W tym ważnym, także w wymiarze symbolicznym dla Drugiej RP, ośrodku olbrzymi wpływ na relacje polsko-żydowskie miał przykład płynący z pobliskiego Gdańska, od 1933 r. rządzonego przez narodowych socjalistó $w^{12}$. Kiedy po śmierci Piłsudskiego zintensyfikowała się antysemicka kampania propagandowa (przejawiająca się m.in. powoła-

${ }^{12}$ Zob. Grzegorz Berendt, Sytuacja ludności żydowskiej w Gdyni w II Rzeczypospolitej, „Biuletyn ŻIH" 1993, nr 1/2 (165/166), s. 88-89. 
niem stałych lokalnych komitetów antyżydowskich, bojkotem przedsiębiorstw żydowskich oraz aktywnością segregacyjną w stowarzyszeniach publicznych), znowu miejsce i rola organizacji rozłamowych okazywały się, poza wyjątkami, znikome. Bez mała całą przestrzeń polityki prawicowej zagospodarowało SN. Wraz z aktywnością bojkotową postępowały systematyczne, niemal codzienne fizyczne ataki na Żydów. W 1937 r. tego rodzaju działania znalazły w Gdyni wsparcie prorządowych organizacji, m.in. lokalnego oddziału Polskiego Związku Zachodniego czy Związku Popierania Polskiego Stanu Posiadania, wzywających do bojkotu „elementu obcego narodowościowo"13. Nie do końca rozpoznana jest rola, jaką w tym antysemickim przesileniu odgrywał Związek Młodej Polski, paramilitarna organizacja faszystowska powstała w ramach OZN (czerwiec 1937) - Szymon Rudnicki poświęca tej formacji jeden z podrozdziałów swego studium - w innych regionach Polski znana głównie z agresywnej akcji bojkotowej, terroryzowania działaczy lewicy i wywoływania burd antyżydowskich. Za niemal wszystkimi tymi przedsięwzięciami stał natomiast rozbudowany aparat polityczno-organizacyjny SN.

Dziś już wiemy, że oficjalnie deklarowany katolicyzm nie wpływał na tonowanie zachowań przemocowych ani tym bardziej na skalę ekscesów. Wręcz przeciwnie, wraz z bojowo manifestowaną religijnością zwykle rosła agresywność grup zaangażowanych w przemoc. Wystąpienia wyższego duchowieństwa katolickiego z wiosny 1936 r. (m.in. homilie prymasa Polski kard. Augusta Hlonda czy bp. Adama Sapiehy, metropolity krakowskiego), enuncjacje katolickich intelektualistów, np. Zofii Kossak-Szczuckiej w „Prosto z Mostu” czy w poznańskiej „Kulturze”, wzywające do dystansowania się od przemocy antysemickiej, zawierające przy tym postulaty segregacyjne wobec Żydów, były zwykle odbierane w kręgach nacjonalistycznych jako aprobata dla akcji bojkotowej. Do bojkotu Żydów otwarcie wzywała przecież masowa prasa katolicka, począwszy od „Małego Dziennika” wydawanego przez o. Maksymiliana Kolbego, po tysiące innych tytułów (nakłady tej prasy szacuje się prawie milion egzemplarzy). Opiniotwórcza prasa nacjonalistyczna, taka jak związany z SN tygodnik „Myśl Narodowa” czy sympatyzujący z wszystkimi odłamami „młodych” „Prosto z Mostu”, w odróżnieniu od prasy codziennej (centralnego organu SN „Warszawski Dziennik Narodowy" czy największego dziennika agitacyjnego dzielnic zachodnich "Orędownik"), nie relacjonowały szczegółowo ani przebiegu wypadków, ani następujących po nich procesów sądowych - kolejnego etapu w tych rewiach przemocy. $\mathrm{W}$ prasie codziennej $\mathrm{z}$ kolei strategia była inna: wypadki wręcz eksponowano, obficie kreśląc obraz odwiecznej, nieuniknionej wojny polsko-żydowskiej, w której kolektywna przemoc antyżydowska była tylko bieżącą brutalną odsłoną. 0 tym wszystkim jednak już z grubsza wiadomo; dopie-

${ }^{13}$ Tego rodzaju praktyki były też częste w innych województwach; zob. m.in. Adam Puławski, Antysemickie jednodniówki na chełmskim rynku wydawniczym (1929-1939), „Rocznik Chełmski” 2016, nr 19, s. 140-145. 
ro dokładne, systematyczne i szczegółowe badania archiwalno-źródłowe, a także przekrojowe studia poszczególnych przypadków pokazałyby faktyczną skalę terroru antysemickiego w Polsce i trwały ślad, jaki „polski faszyzm” zostawił po sobie w społeczeństwie.

Przez długi czas o faszyzmie w polskim dyskursie publicznym nie mówiono inaczej niż w formie inwektywy politycznej. Pierwszy krok w tej materii zrobili rządzący po wojnie komuniści, którzy z mniejszym lub większym skutkiem próbowali z elit Drugiej Rzeczypospolitej uczynić faszystów en masse, a samo zjawisko polityczno-kulturowe kryminalizować. Polityczne przyczyny tych zabiegów wydają się oczywiste; powody, które za nimi stały, były jednak głębsze - u ich podstaw tkwiła trauma społeczno-kulturowa, jakiej doświadczyły zarówno lewica, jak i środowiska liberalne późnych lat trzydziestych. Potem jednak, po 1956 r., zwykle ten fenomen skutecznie wypierano z narodowej pamięci („osobliwa terapia narodowej zgody" według Adama Michnika), choć o tych strategiach bagatelizowania "faszyzmu” w debacie publicznej było wiadomo.

W powszechnym, ugruntowanym podręcznikami i przez system szkolny, mniemaniu faszyzm był i pozostał zjawiskiem marginalnym w dziejach Polski, zasadniczo ograniczonym do społeczności studenckiej i cząstkowo warstw niższych, głównie do miejskiego lumpenproletariatu, a terytorialnie do kilku miast akademickich. Jego największym, pośrednim sukcesem zdaje się wprowadzenie numerus clausus na uniwersytetach, a także elementów tzw. getta ławkowego w drugiej połowie lat trzydziestych. Ten uproszczony obraz nie jest jednak prawdziwy.

W badaniach historiograficznych, które są przecież w jakiejś mierze odbiciem świadomości społecznej, również widać pewne zwroty, które określiły współczesne rozumienie faszyzmu. Bodaj jako pierwszy syntezy tego toku rozumowania na bogatym materiale źródłowym dokonał Krzysztof Kawalec, historyk myśli politycznej związany z Uniwersytetem Wrocławskim, w opublikowanej w okresie przełomu politycznego 1989 r. książce dotyczącej relacji zachodzących między Narodową Demokracją a faszyzmem, przy czym autor potraktował to zjawisko nie jako włoski przeszczep, lecz jako szerszy europejski fenomen ${ }^{14}$. Choć wiele ustaleń tej syntetycznej i ciągle istotnej dla literatury przedmiotu rozprawy wykracza poza zakres tematyczny tego szkicu, wypada odnotować, że Kawalec wyraźnie sytuował rodzimą refleksję nacjonalistyczną, w tym jej główny nurt p o z a dziejami europejskiego faszyzmu lub niejako o b o k niego. „Pokusa i totalitarne inspiracje", zdaniem tego badacza, synonimiczne z faszyzmem ujawniały się przede wszystkich na marginesie różnych nurtów polskiego na-

${ }^{14}$ Krzysztof Kawalec, Narodowa Demokracja wobec faszyzmu 1922-1939. Ze studiów nad dziejami myśli politycznej obozu narodowego, Warszawa: PIW, 1989. 
cjonalizmu, a przyswojenie poszczególnych rozwiązań odbywało się już raczej $\mathrm{w}$ środowiskach drugorzędnych i najbardziej zmarginalizowanych ${ }^{15}$. Do pewnego stopnia można uznać, że Kawalec w swoim erudycyjnym wywodzie wyznaczył ramy polskich debat o faszyzmie na najbliższe lata, ten schemat bowiem powtarza się w dziesiątkach studiów.

W szerszym tle tego nurtu sytuują się prace rekonstruujące dzieje polskiego nacjonalizmu głównie z zakresu historii idei. Pod tym kątem na szczególną uwagę zasługują publikacje Bogumiła Grotta - historyka i zarazem politologa związanego z ośrodkami akademickimi Krakowa - badającego związki rodzimego nacjonalizmu $\mathrm{z}$ religią. 0 ile jeszcze $\mathrm{w}$ pierwszych tekstach, ukazujących się na przełomie lat siedemdziesiątych i osiemdziesiątych, autor ten skupiał się na kształtowaniu osobliwego, jego zdaniem, splotu między nacjonalizmem a katolicyzmem, o tyle później wyraźnie usiłował problematykę nowoczesnego nacjonalizmu ujmować według kryterium religijnego - w jego przekonaniu nacjonalizm wywodzący się z krajów i kultur „katolickich” jest bardziej umiarkowany, a w aspiracjach ideologicznych konserwatywny i ograniczony, natomiast nacjonalizm krajów i kultur „protestanckich” bądź „prawosławnych” niejako z natury ulega większej pokusie i ciśnieniu ze strony ekstremizmów. Ten drugi $\mathrm{w}$ nieunikniony sposób wikła się $\mathrm{w}$ relacje z przemocą i staje się faszyzmem ${ }^{16}$. „Nacjonalizm chrześcijański” (tj. zwykle katolicki) w takim ujęciu pozostawał mniej podatny, jeśli w ogóle, na procesy faszyzacji, a agresywny antysemityzm - zjawisko, które trudno pominąć przy badaniu polskiego nacjonalizmu lat trzydziestych XX w. nawet największym apologetom - w zasadzie pokrywał się $\mathrm{z}$ tradycyjnymi uprzedzeniami. W tym rozumowaniu Grott, podobnie jak większość autorów identyfikujących się z nurtem etno-nacjonalistycznym, usiłuje uzasadniać pojawienie się nawet najbardziej drapieżnych przypadków judeofobii obiektywnymi sprzecznościami interesów, obcością kulturową, w końcu rzekomym separatyzmem, jaki miał się ujawnić w stosunkach między Polakami i Żydami od początku XX w. ${ }^{17}$ Faszyzm to dla tego nurtu albo organizacje mające w nazwie słowo "faszyzm” bądź „narodowy socjalizm”" chrześcijańskiego (tj. dla tych autorów nieodmiennie katolickiego) dziedzictwa bądź wręcz je odrzucające. W podkreślaniu przynależności etnicznej kryje się

${ }^{15}$ Zob. Krzysztof Kawalec, Spadkobiercy niepokornych. Dzieje polskiej myśli politycznej 1918-1939, Wrocław-Warszawa-Kraków: Zakład Narodowy im. Ossolińskich, 2000. Por. także idem, Wizje ustroju państwa w polskie myśli politycznej lat 1918-1939. Ze studiów nad dziejami myśli politycznej, Wrocław: Wydawnictwo Uniwersytetu Wrocławskiego, 1995.

${ }^{16}$ Podsumowanie licznych studiów Bogumiła Grotta zawiera praca pt. Dylematy polskiego nacjonalizmu. Powrót do tradycji czy przebudowa narodowego ducha (Warszawa: Wydawnictwo Von Borowiecky, 2014).

${ }^{17}$ Podobną optykę przyjmuje Mieczysław Sobczak, zob. przede wszystkim idem, Narodowa Demokracja wobec kwestii żydowskiej w Polsce w latach 1918-1939, Wrocław: Uniwersytet Ekonomiczny, 1998.

${ }^{18}$ Por. Olgierd Grott, Faszyści i narodowi socjaliści w Polsce, Kraków: Nomos, 2007. 
rzecz jasna pewna nie zawsze niewypowiedziana otwarcie, lecz wyraźna myśl: „faszyzm” był w Polsce zasadniczo niemożliwy.

Nurt krytyczny wobec spuścizny nacjonalistycznej, skupiający się m.in. wokół prac Janusza Jerzego Tereja ${ }^{19}$ i przede wszystkim Szymona Rudnickiego, historyków związanych przede wszystkim z Uniwersytetem Warszawskim, inspiracje faszystowskie, potem także nazistowskie odnotowywał (m.in. kluczową rolę radykalnego antysemityzmu) jako ważny i nie do pominięcia etap późnej ewolucji rodzimego projektu nacjonalistycznego ${ }^{20}$. Pionierska, a zarazem klasyczna w tym zakresie praca Rudnickiego wiele mówiła o tym organicznym funkcjonowaniu narodowego radykalizmu wewnątrz polskiego nacjonalizmu.

Rudnicki, choć jego ujęcie jest polemiczne wobec tradycji nacjonalistycznej, unika jednak z jednej strony otwartej dyskusji z historiografią hagiograficzną, która od przynajmniej dwóch dekad zdominowała badania nad nurtami i dziedzictwem „polskiego faszyzmu”, z drugiej zaś zdawkowo odnosi się do podejścia etno-nacjonalistycznego. Na tle publikacji obu tych kierunków Falanga z pewnością pod wieloma względami się wyróżnia: autor stara się maksymalnie rzetelnie rekonstruować materiał źródłowy, pokazywać go z wielu perspektyw, nie tylko tych krytycznych, lecz także tych aprobujących i pozytywnych, zwykle pozostawiając czytelnikowi samodzielne wyprowadzenie wniosków i konkluzji. Ten programowy, aczkolwiek rozumiejący pozytywizm unika kategoryzacji, choć nie pomija też tzw. trudnych kwestii, co zwykle dominuje w polskim piśmiennictwie, dostarcza za to olbrzymiego kwantum wiedzy. Nikt nie może mieć wątpliwości, że Szymon Rudnicki jest największym autorytetem, jeśli chodzi o znajomość zarówno źródeł, jak i ewolucji oraz rozwoju nacjonalistycznego radykalizmu czy, szerzej, nacjonalizmu na ziemiach polskich przełomu XIX i XX w.

Rudnicki już $\mathrm{w}$ połowie lat osiemdziesiątych wzniósł solidne fundamenty pod badania nad polskim faszyzmem, choć wtedy jeszcze, być może także ze względów cenzuralnych, to określenie w jego pracach pojawiało się zdawkowo. Aby jednak zrozumieć powab, atrakcyjność i przede wszystkim nośność, jaką dla kultury politycznej dwudziestolecia międzywojennego, a także później miały idee faszystowskie - przypomnijmy dla porządku, nie tylko w Polsce - trzeba pójść dalej.

Od mniej więcej dekady zainteresowany czytelnik ma dostęp do większości tekstów programowych tych środowisk. W piśmiennictwie pojawił się również, co było zapewne nie do uniknięcia, nurt apologetyczno-hagiograficzny wobec

${ }^{19}$ Jerzy Janusz Terej, Idee, mity, realia. Szkice do dziejów Narodowej Demokracji, Warszawa: Wiedza Powszechna, 1971. Por. także idem, Rzeczywistość i polityka. Ze studiów nad dziejami Narodowej Demokracji, wyd. 2 popr. i uzup., Warszawa: Książka i Wiedza, 1979.

${ }^{20}$ Por. Szymon Rudnicki, Obóz Narodowo-Radykalny. Geneza i działalność, Warszawa: Czytelnik, 1985, tu s. 13, 22. W tym duchu należy też odnotować pracę niemieckiego historyka polskiego pochodzenia Alberta S. Kotowskiego Narodowa Demokracja wobec nazizmu i Trzeciej Rzeszy (Toruń: Wydawnictwo Adam Marszałek, 2006). 
tej tradycji. W tych publikacjach już nie tylko topornie lub na bakier $\mathrm{z}$ faktografią tłumaczy się zarówno drapieżny antysemityzm, jak i przemoc polityczną ${ }^{21}$, lecz także postępującą faszyzację ugrupowań nacjonalistycznych ${ }^{22}$. To polityczno-ideologiczne uwstecznienie - ktoś mógłby powiedzieć: recydywa z przeszłości - jest dotkliwym, ale nie jedynym problemem ${ }^{23}$.

Pierwszym postulatem badawczym musi być przesunięcie wysiłku analitycznego z ideologii, myśli i idei, dyskursów i narracji publicznych na działania i społeczne praktyki prawicowego radykalizmu z lat trzydziestych. Na podstawie dostępnej literatury przedmiotu - a przekrojowe studium Rudnickiego zawiera pod tym względem nową porcję drobiazgowego materiału ilustracyjnego - wydaje się on liczniejszy, znacznie głębiej sięgający i odciskający piętno, niż wskazywały polityczne wpływy radykalnego habitusu w obrębie całej sceny prawicowej. Żeby jednak oszacować skalę tego zjawiska, a przede wszystkim zrozumieć, jakie były jego konsekwencje społeczne i polityczne, potrzebujemy nieco innej wiedzy i zestawu innych narzędzi. Z pewnością jednym z takich wielkich wyzwań, przed jakimi muszą stanąć nie tylko historycy, jest trwały ślad pozostawiony wtedy na polskiej prowincji i w lokalnych społecznościach przez wielki kryzys i postępującą po nim depresję gospodarczą.

Bezrobocie, sięgające $w$ niektórych regionach ponad 50 procent pracujących, niosło za sobą nie tylko biedę i głód, lecz także rozpacz i przede wszystkim upokorzenie. Wszystkie te zjawiska przyciągały różnego rodzaju patologie społeczne na skalę wcześniej nieznaną, znieczulały też na przemoc, która z kolei coraz częściej było postrzegana jako remedium. Najpierw wśród elit i intelektualistów, nie tylko zresztą prawicowej proweniencji, widziano w przemocy ostateczny regulator stosunków międzynarodowych, z czasem zaś przeświadczenia o jej skuteczności nabrały masy. Wtedy przemoc, co ciągle bywa przeoczane, przeniosła się na ulicę.

${ }^{21}$ Wojciech Jerzy Muszyński, jeden z prominentnych przedstawicieli tego kierunku, we wstępie do reprintu Kartek $z$ więzienia autorstwa zabójcy prezydenta Gabriela Narutowicza Eligiusza Niewiadomskiego, pisze o tym tekście mającym jednoznacznie antysemicką wymowę jako manifeście odwagi cywilnej i nonkonformizmu (idem, Wstęp [w:] Eligiusz Niewiadomski, Kartki z więzienia, Warszawa: Capital, 2013, s. 2-7; por. także https://nczas.com/2013/01/31/ eligiusz-niewiadomski-czyli-o-autorze-kartek-z-wiezienia-wojciech-muszynski/, dostęp 1 IX 2019 r.).

${ }^{22}$ Wspomniany w poprzednim przypisie Wojciech Muszyński wraz z Jolantą Mysiakowską-Muszyńską gdzie indziej dowodzą, że bohater ich publikacji Roman Dmowski tworzył faszyzujące ruchy, takie jak OWP, a potem dbał o to, „aby reformy, które zapoczątkował, nie były zbyt daleko posunięte, aby jego obóz nie nabrał cech totalitarnych i nie przekształcił się w polską odmianę faszyzmu". Ta wysokonakładowa publikacja, wydana na luksusowym papierze przez Instytut Pamięci Narodowej, ukazała się z okazji setnej rocznicy odzyskania niepodległości (eidem, Architekt Wielkiej Polski Roman Dmowski (1864-1939), Warszawa: Instytut Pamięci Narodowej, 2018, s. 276).

${ }^{23} \mathrm{O}$ tym zagadnieniu pisałem na łamach „Zagłady Żydów”, zob. O klerykalnym faszyzmie po latach. Na marginesie „Curriculum Vitae” Jędrzeja Giertycha, „Zagłada Żydów. Studia i Materiały" 2013, nr 9. 
Historycy gospodarczy podpowiadają, że już w 1937 r. kryzys w wielkich polskich miastach, takich jak Warszawa, Łódź czy miasta śląskie, się kończył; na polskiej prowincji, w małych miasteczkach i osadach czy na wsi, gdzie żyło prawie 70 procent społeczeństwa Drugiej Rzeczypospolitej, trwał jednak aż do wybuchu wojny. Pamięć społeczna o nim przetrwała Drugą Rzeczpospolitą, drugą wojnę światową, a nawet komunizm i zasadniczo nie została, jak się wydaje, do końca zrozumiana ani tym bardziej przepracowana. Polska humanistyka przede wszystkim badacze z kręgu Wolnej Wszechnicy Polskiej, a także socjologowie z kręgu Floriana Znanieckiego, Stefana Czarnowskiego czy Józefa Obrębskiego - poczyniła olbrzymi wysiłek badawczy, żeby udostępnić zdobytą wiedzę i na te emocje uwrażliwić. Historycy muszą tę wiedzę wykorzystać i wprowadzić ją do obiegu publicznego. Kolejnym krokiem będzie zapewne dalszy zwrot ku historii społecznej i może jeszcze bardziej mikrohistorii, co pozwoli pokazać tamte wypadki „od dołu”. Nikt chyba nie ma już złudzeń, że będzie to wiedza bolesna. Warto ją zgłębiać nie dla uczucia dumy ani tym bardziej wstydu, jak suflują niektórzy elokwentni dziejopisarze, ale by zrozumieć teraźniejszość.

Jedną z ciągle niezbadanych przestrzeni badawczych wydaje się penetracja idei i mentalności faszystowskiej w establishmencie władzy. Większość polskich badaczy - a niejednokrotnie powtarzają to za nimi zagraniczne opracowania bagatelizuje bądź jeszcze częściej wtórnie racjonalizuje wpływy faszystowskie w kręgach władzy. Obóz Zjednoczenia Narodowego uznaje się zwykle za twór politycznie nieudany, raczej kolejny przejaw urzędniczego konformizmu - tak jakby to właśnie konformizm nie był jednym ze źródeł reżymów faszystowskich - wobec autorytarnej władzy niż przykład jej realnych zdolności mobilizacyjnych. Faszyzm jako strategia rządzących, budowany od góry, nie jest jednak niczym nowym. Także Szymon Rudnicki wpływ idei i mentalności faszystowskiej, obecność jej istotnych składników - m.in. zarządzanej odgórnie militaryzacji społeczeństwa, w tym wzrastającej roli formacji paramilitarnych, postępującej konsolidacji społeczeństwa wokół odgórnie kreowanych wrogów, antysemityzmu politycznego $\mathrm{z}$ rozbudowanymi praktykami dyskryminacyjnymi wobec mniejszości, ogólnopolskich nagonek (np. w 1938 r. na masonerię czy środowiska nauczycielskie), strategii mobilizacji społecznej wokół agresywnego nacjonalizmu, haseł mocarstwowych i, bagatela, kolonialnych, produkowania charyzmy politycznej przywódców etc. - ogranicza do szeroko rozumianego obozu nacjonalistycznego, uznając wprost rodzimy faszyzm za dziecko nacjonalizmu. Na pierwszy rzut oka trudno z takim ujęciem dyskutować, ale jest ono już niewystarczające. Bez wielkiej przesady można uznać, że faszyzm, choć gęsto podlewany importem z Europy Zachodniej, wyrósł na gruncie rodzimego nacjonalizmu. Wyzwanie dla historiografii stanowi ustalenie, jak dalece ten typ kultury politycznej, z przemocą polityczną jako podstawowym miernikiem wartości, pozostawał dominującym wzorem kultury, przez który przeszło, bez względu na podziały polityczne, całe pokolenie młodych ludzi, a wiele grup społecznych - nieraz całe regiony - zostało pod jego wpływem ukształtowanych. 
W dość rozpowszechnionym mniemaniu to raczej włoski faszyzm stanowił dla polskich naśladowców podstawowy punkt odniesienia. Opiniotwórczy publicysta Adam Michnik pisał np.: „W latach 30. faszyzm, głównie w wersji włoskiej Mussoliniego, fascynował część elity kulturalnej młodego pokolenia Polaków. Zdawał się nowym projektem cywilizacji, podczas gdy demokracja liberalna skazana była na śmierć. Językiem, który zbliżał, czy też miał zbliżać, elity intelektualne skrajnej prawicy do Polski plebejskiej, był antysemityzm"24. Michnik, jak zresztą wielu innych, utrzymuje zarazem, że „polski faszyzm był antyniemiecki i antyhitlerowski, ale nie przestawał być faszyzmem". To założenie znane, potwierdzone wypadkami z 1939 r. i potem, ale nie do końca prawdziwe. Mussolini wraz z partią faszystowską rzeczywiście przez pierwszą dekadę międzywojnia stanowił kluczowy punkt odniesienia dla całej, nie tylko europejskiej, prawicy. Później jednak scena prawicowa w Polsce, jak zresztą wszędzie w Europie, choć we wschodniej jej części widać to mocniej i dobitniej, przeszła bowiem fascynację hitleryzmem. Aleksander Hertz nie bez powodu na początku lat trzydziestych nazywał „obwiepolaków” (tj. członków OWP) „polskimi hitlerowcami"; już wtedy kolejne tryumfy polityczne narodowych socjalistów relacjonowała niemal cała prasa nacjonalistyczna. Wyczytać tę fascynację można nie tylko w entuzjastycznych korespondencjach z Berlina i innych miast niemieckich, w artykułach zamieszczanych w prasie opiniotwórczej i w wypowiedziach elit, lecz także na polskiej prowincji, gdzie metody, którymi „Hitler robi porządek", wywoływały gwałtowne poruszenie. Dlaczego? Między innymi ze względu na to, że narodowy socjalizm rozwiązywał centralne z punktu widzenia rodzimych „narodowców” „zagadnienie żydowskie”. Po 1933, zwłaszcza po 1934 r., kiedy Hitler uczynił Drugą Rzeczpospolitą obiektem swych zabiegów politycznych, a Trzecia Rzesza stanęła dla polskich elit otworem, to oddziaływanie wzorcotwórcze nazizmu jeszcze wzrosło. Polscy studenci DAAD (Deutscher Akademischer Austauschdienst) poza rumuńskimi, którzy również masowo pielgrzymowali wtedy do „narodowych Niemiec”, byli najliczniejsi. Do hitlerowskich Niemiec jeździli polscy harcerze, by uczyć się od Hitlerjugend metod zarządzania „narodowym” wychowaniem młodzieży, i pracownicy opieki społecznej, żeby zgłębiać historię sukcesu narodowosocjalistycznego Sozialstaat, a także prokuratorzy, w szczególności za czasów ministra Witolda Grabowskiego (1936-1939, zwolennika twardej ręki, wcześniej m.in. głównego oskarżyciela podczas słynnego procesu brzeskiego), aby skutecznie tropić „komunę"25. $\mathrm{W}$ walce $\mathrm{z}$ „międzynarodowym komunizmem”, m.in. w czasie wojny domowej w Hiszpanią, zgodnie współpracowały wywiady polski i niemiecki.

${ }^{24}$ Adam Michnik, Czy to już faszyzm?, „Gazeta Wyborcza”, 25-26 V 2019.

${ }^{25}$ Tę problematykę sygnalizuje w klasycznym już studium Edward W. Wynot Jr. (idem, Polish Politics in Transition: The Camp of National Unity and the Struggle for Power, 1935-1939, Athens: University of Georgia Press, 1974). 
Nie chodziło bynajmniej o bierne naśladownictwo. Nie wszystko polskim „narodowcom” w Niemczech się podobało i nie tak wielu, jak np. Stanisław Brochwicz (prominentny działacz Falangi, a przy tym publicysta sanacyjnej „Polski Zbrojnej"), przekroczyło granicę narodowego zaprzaństwa, ale wiele wzorów i pomysłów chcieli przenieść do swojego kraju. Podobnie było w innych grupach. W tym świetle głośny, choć znowu zwykle skrzętnie przemilczany artykuł redakcyjny Żądamy polskiego „, hitleryzmu”, opublikowany na łamach wydawanej przez Jerzego Giedroycia „Polityki”, nie wydaje się tak szokujący ${ }^{26}$. Skalę, zakres i niejednoznaczne kierunki tych zapożyczeń warto będzie jeszcze prześledzić. Zagadnienie transakcji i zapożyczeń ideowych otwiera na kolejny, może jeszcze bardziej zapoznany, problem. Druga Rzeczpospolita nie tylko dostała się pod wpływy międzynarodowego faszyzmu, lecz była także laboratorium innych radykalnych nacjonalizmów etnicznych, przede wszystkim żydowskiego i ukraińskiego. Zwykło się je wydzielać i uznawać za półprodukt importu z zagranicy, reakcję obronną i w związku z tym skutecznie wypierać z pamięci historycznej; najwyższy już czas, żeby je zintegrować z rodzimymi dziejami.

Faszyzm w Polsce przed 1939 r. ostatecznie nie zwyciężył; ani nie zdobył pełni politycznej władzy, ani nie stworzył masowego ruchu poparcia w postaci jednego ośrodka z charyzmatycznym przywództwem, jak się to stało we Włoszech a potem w Niemczech. Niemniej, jak wiele wskazuje, nie tylko w obrębie nacjonalistycznej prawicy, lecz także w kluczowych dla elit środowiskach społecznych, m.in. w Kościele katolickim, w kręgach władzy, w elitach wojskowych stawał się jednym z najważniejszych punktów odniesienia, a jego wpływy społeczno-kulturowe znacznie wykraczały poza wyniki wyborcze. Wiele przemawia za tym, że po przełomie 1933 i 1934 r. zmienił rodzimą prawicową scenę, a jednocześnie nadał polskiej polityce dynamikę, z której wyzwoliła ją dopiero druga wojna światowa. Czy aby do końca? Nie ulega najmniejszej kwestii, że to, co jeszcze na początku lat trzydziestych pojawiło się jako hasło-manifest, deklaracja na wyrost, $\mathrm{w}$ drugiej połowie dekady stawało się rzeczywistością społeczno-polityczną. Procesy, które ujawniły się w polityce polskiej tamtego czasu, miały długotrwałe efekty uboczne: skrajną polaryzację, nienawiść i potęgującą się agresję między poszczególnymi ugrupowaniami, a w praktyce podziały między poszczególnymi grupami społecznymi, segregację i w końcu anomię mniejszości etnicznych i religijnych.

Szymon Rudnicki podniósł wysoko poprzeczkę badań na kulturą polityczną polskiej prawicy pierwszej połowy XX w. Następców czeka jednak wysiłek, by tę wiedzę przyswoić i zrozumieć, a następnie przepisać na współczesność. Potrzebują jej nie tylko historycy, lecz przede wszystkim świadomi obywatele, żeby tej lekcji z przeszłości po raz kolejny, niczym w lunatycznym śnie, nie powtarzać.

${ }^{26}$ Żqdamy polskiego „hitleryzmu”, „Polityka”, 25 II 1939, nr 4, s. 1. 


\section{BIBLIOGRAFIA}

Bechta Mariusz, Narodowo radykalni. Obrona tradycji i ofensywa narodowa na Podlasiu w latach 1918-1939, Biała Podlaska: Rekonkwista, 2014.

Berendt Grzegorz, Sytuacja ludności żydowskiej w Gdyni w II Rzeczypospolitej, „Biuletyn ŻIH” 1993, nr 1/2 (165/166).

Danek Adam, Demokracja nacjonalistyczna. O myśli politycznej Zygmunta Cybichowskiego, Kraków: Ośrodek Myśli Politycznej, 2018.

Dawidowicz Aneta, Myśl polityczna Stronnictwa Narodowego 1928-1939, Lublin: Wydawnictwo UMCS, 2017.

Grott Bogumił, Dylematy polskiego nacjonalizmu. Powrót do tradycji czy przebudowa narodowego ducha, Warszawa: Wydawnictwo Von Borowiecky, 2014.

Grott Olgierd, Faszyści i narodowi socjaliści w Polsce, Kraków: Nomos, 2007.

Kawalec Krzysztof, Narodowa Demokracja wobec faszyzmu 1922-1939. Ze studiów nad dziejami myśli politycznej obozu narodowego, Warszawa: PIW, 1989.

Kawalec Krzysztof, Spadkobiercy niepokornych. Dzieje polskiej myśli politycznej 19181939, Wrocław-Warszawa-Kraków: Zakład Narodowy im. Ossolińskich, 2000.

Kawalec Krzysztof, Wizje ustroju państwa w polskie myśli politycznej lat 1918-1939. Ze studiów nad dziejami myśli politycznej, Wrocław: Wydawnictwo Uniwersytetu Wrocławskiego, 1995.

Kijek Kamil, Zanim stał się Przytyk. Ruch narodowy a geneza zajść antyżydowskich w wojewódzkie kieleckim w latach 1931-1935, „Zagłada Żydów. Studia i Materiały” 2018, nr 14.

Kotowski Albert S., Narodowa Demokracja wobec nazizmu i Trzeciej Rzeszy, Toruń: Wydawnictwo Adam Marszałek, 2006.

Krzywiec Grzegorz, O klerykalnym faszyzmie po latach. Na marginesie „Curriculum Vitae” Jędrzeja Giertycha, „Zagłada Żydów. Studia i Materiały” 2013, nr 9.

Michnik Adam, Czy to już faszyzm?, „Gazeta Wyborcza”, 25-26 V 2019.

Miłosz Czesław, Faszyzm (1945) [w:] idem, W cieniu totalitaryzmów. Publicystyka rozproszona z lat 1945-1951 oraz teksty z okresu II wojny światowej, red. Aleksander Fiut, Kraków: Wydawnictwo Literackie, 2018.

Muszyński Wojciech Jerzy, Jolanta Mysiakowska-Muszyńska, Architekt Wielkiej Polski Roman Dmowski (1864-1939), Warszawa: Instytut Pamięci Narodowej, 2018.

Muszyński Wojciech Jerzy, Wstęp [w:] Eligiusz Niewiadomski, Kartki z więzienia, Warszawa: Capital, 2013, https://nczas.com/2013/01/31/eligiusz-niewiadomski-czylio-autorze-kartek-z-wiezienia-wojciech-muszynski/.

Puławski Adam, Antysemickie jednodniówki na chełmskim rynku wydawniczym (19291939), „Rocznik Chełmski” 2016, nr 19.

Rudnicki Robert, Wiesław Ignacy Renke (1912-1944). Życie i działalność kierownika politycznego Obozu Narodowego, Warszawa: Prohibita, 2018.

Rudnicki Szymon, Falanga. Ruch Narodowo-Radykalny, Warszawa: Wydawnictwo ASPR-JR, 2018.

Rudnicki Szymon, Obóz Narodowo-Radykalny. Geneza i działalność, Warszawa: Czytelnik, 1985.

Sikorski Tomasz, Żelazny krok potężnych zdyscyplinowanych szeregów... Oblicze ideowo-polityczne środowiska „Zaczynu” (1936-1939). Studium z dziejów myśli politycznej piłsudczyków, Warszawa: Wydawnictwo von Borowiecky, 2014.

Sobczak Mieczysław, Narodowa Demokracja wobec kwestii żydowskiej w Polsce w latach 1918-1939, Wrocław: Uniwersytet Ekonomiczny, 1998. 
Stanowisko Stronnictwa Narodowego, „Myśl Narodowa”, 2 V 1937, nr 18.

Terej Jerzy Janusz, Idee, mity, realia. Szkice do dziejów Narodowej Demokracji, Warszawa: Wiedza Powszechna, 1971.

Terej Jerzy Janusz, Rzeczywistość i polityka. Ze studiów nad dziejami Narodowej Demokracji, wyd. 2 popr. i uzup., Warszawa: Książka i Wiedza, 1979.

Tomasiewicz Jarosław, Naprawa czy zniszczenie demokracji? Tendencje autorytarne i profaszystowskie w polskiej myśli politycznej 1921-1935, Katowice: Wydawnictwo Uniwersytetu Śląskiego, 2012.

Wynot Edward W. Jr., Polish Politics in Transition: The Camp of National Unity and the Struggle for Power, 1935-1939, Athens: University of Georgia Press, 1974.

Z bojów Adolfa Nowaczyńskiego. Wybór źródeł, t. 3: W cieniu swastyki (1932-1934), red. Arkadiusz Meller, Sebastian Kosiorowski, Warszawa: Wydawnictwo von Borowiecki, 2018.

Żądamy polskiego „hitleryzmu”, „Polityka”, 25 II 1939, nr 4. 